
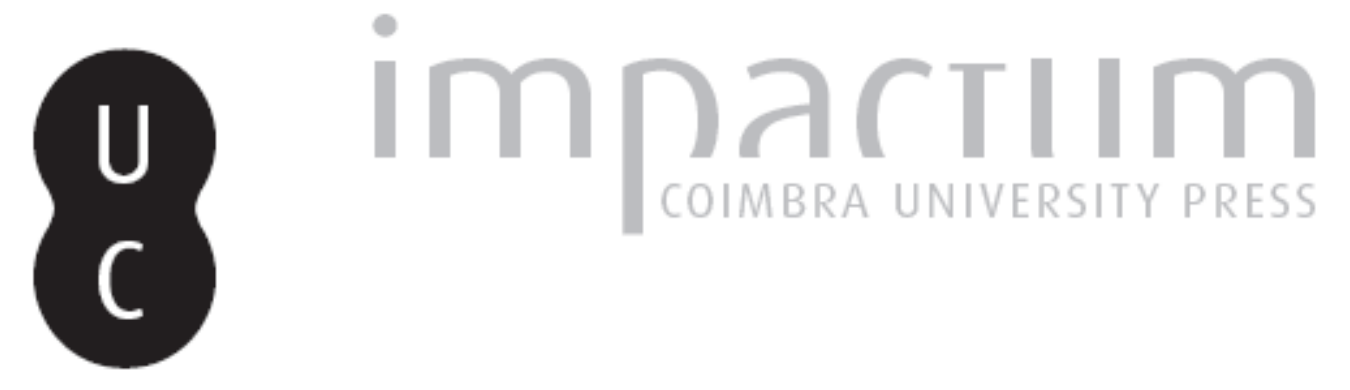

\title{
Plutarch on Aristotle as the first Peripatetic
}

\section{Autor(es): Roskam, Geert}

Publicado por: International Plutarch Society

URL persistente:

URI:http://hdl.handle.net/10316.2/36392

DOI:

DOI:http://dx.doi.org/10.14195/0258-655X_6_3

Accessed : $\quad$ 26-Apr-2023 16:00:59

A navegação consulta e descarregamento dos títulos inseridos nas Bibliotecas Digitais UC Digitalis, UC Pombalina e UC Impactum, pressupõem a aceitação plena e sem reservas dos Termos e Condições de Uso destas Bibliotecas Digitais, disponíveis em https://digitalis.uc.pt/pt-pt/termos.

Conforme exposto nos referidos Termos e Condições de Uso, o descarregamento de títulos de acesso restrito requer uma licença válida de autorização devendo o utilizador aceder ao(s) documento(s) a partir de um endereço de IP da instituição detentora da supramencionada licença.

Ao utilizador é apenas permitido o descarregamento para uso pessoal, pelo que o emprego do(s) título(s) descarregado(s) para outro fim, designadamente comercial, carece de autorização do respetivo autor ou editor da obra.

Na medida em que todas as obras da UC Digitalis se encontram protegidas pelo Código do Direito de Autor e Direitos Conexos e demais legislação aplicável, toda a cópia, parcial ou total, deste documento, nos casos em que é legalmente admitida, deverá conter ou fazer-se acompanhar por este aviso. 


\section{PLOUTARCHOS, n.s.}

Scholarly Journal o

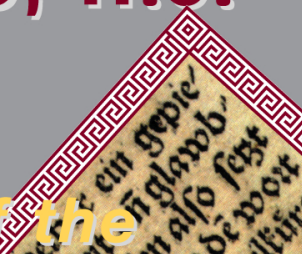

INTERNATIONAL PLUT A N NOS

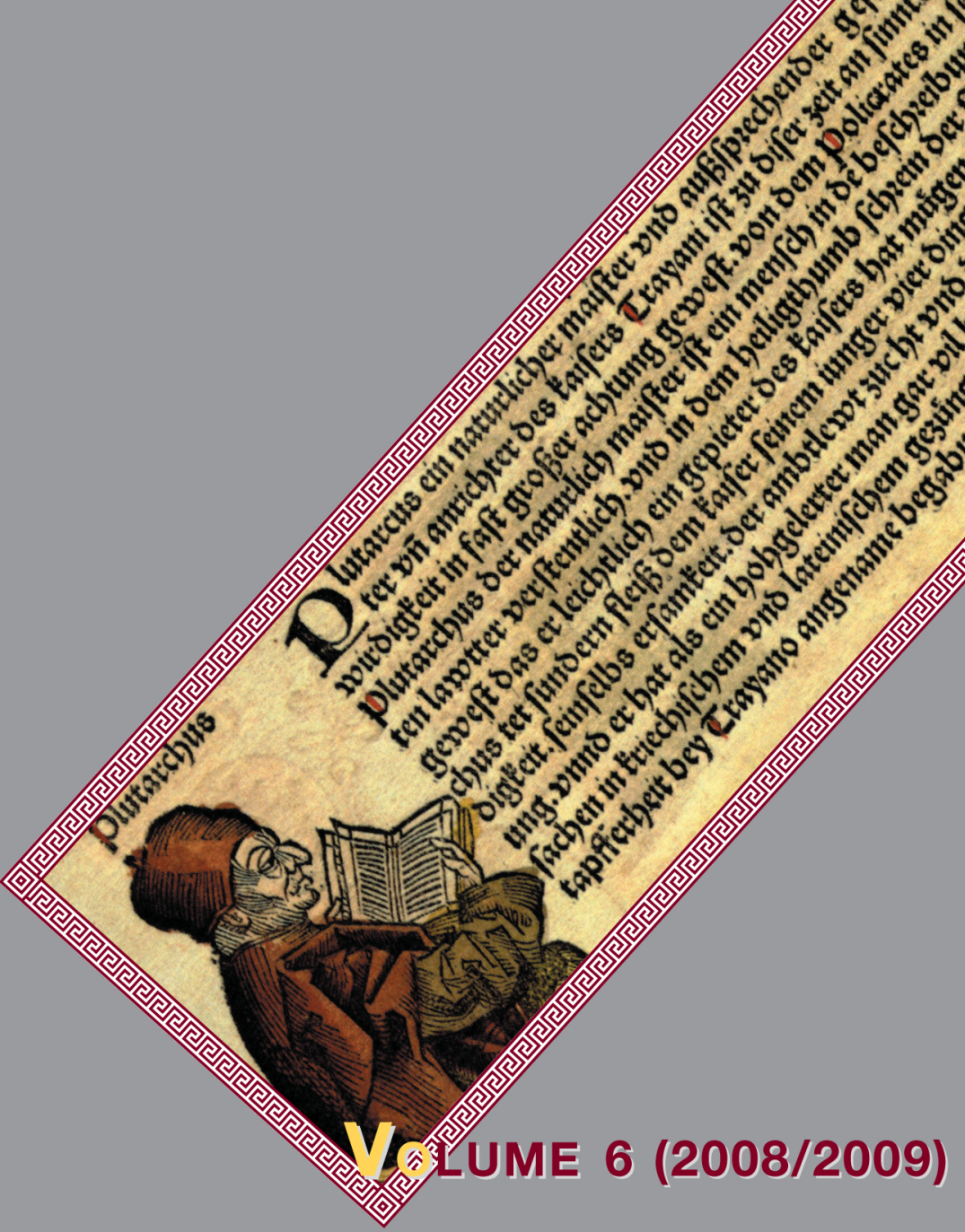

UNIVERSITY of Málaga (SPAin)

Utah State UniVersity, Logan, Utah (U.S.A.) 


\title{
Plutarch on Aristotle as the First Peripatetic ${ }^{1}$ by Geert Roskam K.U.Leuven \\ Geert.Roskam@arts.kuleuven.be
}

\begin{abstract}
This contribution focuses on the question of what place Aristotle occupies in the history of Greek philosophy according to Plutarch. Rather than placing Aristotle in the Platonist or Pythagorean-Platonic tradition, Plutarch regards the Stagirite as the founder of the Peripatetic tradition. Although this philosophical tradition clearly differs from the Platonic one, it remains fairly close to Platonism, so that it can often function as Plutarch's privileged ally in his attacks against other schools.

Key-Words: Plutarch, Aristotle Platonicus, Aristotle Pythagoricus, Aristotle Peripateticus
\end{abstract}

in many different domains. Aristotle

1. Aristotle in Plutarch, or how to find a way out of the labyrinth

is not only referred to in the context of technical philosophical discussions but also quoted for ordinary anecdotes. His

Plutarch's position towards Aristotle view on time, for instance, as measure or has often been examined ${ }^{2}$. Both in the Lives number of motion according to antecedent and in the Moralia, the famous philosopher and subsequent (Quaest. Plat. 1007A) is from Stageira is frequently introduced rejected, whereas his story that Timon's as a respected and authoritative source grandmother every year used to hibernate

1 This is a more elaborate version of a paper that was presented at the conference of the Réseau Plutarque in Málaga, November 28-29, 2008. I would like to thank Jeroen Lauwers for his valuable suggestions, and Ivo Jossart for his competent and much appreciated technical support.

2 Good recent discussions (with further bibliography) can be found in D. BABUT, 1996; A. Pérez Jiménez \& J. García López \& R.M. Aguilar, 1999; and G.E. Karamanolis, 2006. 
for two months (Quaest. conv. $733 \mathrm{C}=\mathrm{fr}$. 43 Rose) is quoted with approval.

Unfortunately, Plutarch's ample use of Aristotle is not free from ambiguities and problems. Usually, his references to, and evaluations of Aristotle's position are fairly brief and directly related to a specific context, and nowhere, he provides a detailed and lengthy discussion of the Stagirite's philosophy. As far as we know, Plutarch never wrote Quaestiones Aristotelicae, and it is extremely doubtful whether he devoted any book length studies to (aspects of) Aristotle's works ${ }^{3}$. Several passages might prima facie suggest a good knowledge of the Corpus Aristotelicum ${ }^{4}$, but on closer inspection, there is only little cogent evidence that points to such thorough familiarity on Plutarch's part ${ }^{5}$. Often, he is rather critical of Aristotle's views. He disagrees, a new light on Plutarch's general attitude for instance, with the latter's doctrine of towards, and use of, the Stagirite. First of

3 The Lamprias catalogue mentions studies on Aristotle's Topics (n. 56), on the Ten Categories (n. 192), and on the Fifth Substance (n. 44). See, however, F.H. SANDBach, 1982, pp. 212 and 216-217; a less sceptical view can be found in D. BABUT, 1996, pp. 8-9 and G.E. Karamanolis, 2006, p. 89 (with n. 15) and p. 338.

4 E.g. Alex. 7,5 (on Aristotle's Metaphysics); De virt. mor. 442BC (with G. Verbere, 1960); Quaest. conv. 616D; Adv. Colot. 1115A-C.

5 In general, I side with the view of F.H. SANDBACH, 1982, esp. p. 230: "Plutarch or his sources knew of Topica, Metaphysics, Nicomachean Ethics, Historia Animalium, Rhetoric III, and probably of De Caelo and De Anima. Direct acquaintance with the contents is certain only for Historia Animalium and Rhetoric III, both books for the use of which before his time there is some evidence"; cf. also P. DoninI, 1974, pp. 66-80.

De def. or. 426D; see F. Ferrari, 1999.

7 See G.E. Karamanolis, 2006, pp. 104-105.

8 Cf., e.g., O. GRÉARD, 1885, p. 58: “C'est la pure doctrine d'Aristote; on ne saurait plus formellement se détacher de Platon"; more references can be found in D. BABUT, 1996, p. 2, n. 2. 
all, however, I would like to warn about Karamanolis provides many arguments for two paths which in my view end in a cul- his hypothesis, carefully discussing many de-sac (section 2). Then I shall try to find relevant passages and dealing with as my own thread of Ariadne, arguing that different domains as metaphysics, natural the most obvious answer is in this case the philosophy, psychology, epistemology, correct one, viz. that Plutarch (correctly) ethics, and logic. Lack of space prevents regards Aristotle as the founder of me from analysing all the evidence in an the Peripatetic philosophical tradition equally detailed way. I confine myself to (section 3.1). This conclusion will not do three important general observations. away with all problems, to be sure, but may help in explaining important aspects of Plutarch's general evaluation and use of Aristotle (section 3.2).

\section{Two dead ends}

\subsection{Aristoteles Platonicus}

In an interesting recent monograph, Karamanolis has argued that Plutarch regarded Aristotle as belonging to the Platonist tradition ${ }^{9}$. NotunlikeAntiochus ${ }^{10}$, Plutarch was convinced, in Karamanolis' view, that Aristotle often preserved Plato's doctrines, but more than Antiochus, he realised that Plato and Aristotle fundamentally differed on many issues, and only used the latter when he represented the former's supposed point of view. the Platonist tradition ${ }^{13}$.

9

10 Although Karamanolis correctly points to the fundamental differences between both thinkers (pp. 87-88).

11 G.E. Karamanolis, 2006, p. 90, borrowing this argument from D. BABUT, 1996, pp. 6-7.

12 See, e.g., B.P. Hillyard, 1981, p. XXvi and L. VAN DER STOCKT, 1987, pp. 283-285.

13 Karamanolis provides (only) one example which in his view shows that Plutarch's familiarity with Aristotle's work "does not necessarily entail abundance of quotations or even references", viz. De sollertia animalium (pp. 90-91). However, the parallels between Plutarch, Sextus Empiricus P. 1,65-75, Porphyry, Abst. 3,3,1-3,18,2, and Philo of Alexandria, Anim. 13-70 show that much material should not be traced back to Plutarch's own reading but to an older anti-Stoic tradition; see already G. TAPPE, 1912, pp. 23-38. 
The second general argument is Devirtutemoralishould be understood derived from Plutarch's way of using in this light as well. According to Aristotle. Karamanolis correctly shows Karamanolis, "Plutarchfeelsentitled touse that Plutarch's use is usually well Aristotle's work in his argument because considered and far from uncritical: "he he maintains that Aristotle preserves was not prepared to accept Aristotle's Plato's ethical doctrine"16. Again, this views when these conflict with what he way of putting the case is too Antiochean considered to be Plato's doctrine. This to my mind. The treatise should primarily means that whenever he uses them, he be understood in the context of Middle does so because he considers them as Platonist ethics, in which Aristotelian and representative of Plato's own doctrines"14. Peripatetic doctrines had already been This is basically correct, but it does not appropriated ${ }^{17}$. It cannot be excluded, necessarily follow that Plutarch also of course, that Antiochus had played considered Aristotle as an exponent of a part in this process of appropriation, Platonism and/or "a communicator of but it is dangerous to connect De virtute Platonist beliefs" (p. 89). As Karamanolis morali with an Antiochean point of perfectly realises himself, Plutarch was view. While Karamanolis, as was said no Antiochus and was in all likelihood above, generally acknowledges the rather critical of the latter's philosophical differences between Plutarch and Anproject ${ }^{15}$. Rather than trying to reconstruct tiochus very well, he comes close to Plato's convictions on the basis of such 'Antiochean' interpretation while Aristotle (and the Stoics), he develops arguing that "it is because Plutarch takes and argues his own views from (what he Aristotle as representative [of] Plato's regards as) a Platonist perspective, and doctrine [...] that he integrates into the also deals with the view of other thinkers Aristotelian doctrine Platonic ideas like from this perspective. In other words, the localization of the parts of the soul Aristotle is for Plutarch not a means to in bodily parts (De virt. mor. 450F) reach a better understanding of Plato, but or the image of the charioteer (445BPlato is and always remains the standard C; Phaedrus 253c-d)"18. In my view, against which all thinkers, including Plutarch is doing exactly the opposite. The Aristotle, are measured. general perspective of De virtute morali

15 Passages such as Cic. 4,1 show that Plutarch regarded Antiochus rather as a Stoic than as an Academic; see D. Babut, 1969b, pp. 198-199; J. Opsomer, 1996, p. 180; ID., 1998, p. 172; contra: A.G. NiKOLAIDIS, 1999, pp. 408-411.

16 G.E. Karamanolis, 2006, p. 116.

17 See esp. P. Donini, 1974, pp. 81-88.

18 G.E. Karamanolis, 2006, p. 121. 
is undoubtedly Plato's philosophy ${ }^{19}$ and quite straightforwardly - although (or what Plutarch regards as such), and admittedly far less often than the Stoics Aristotelian or Peripatetic doctrines are or Epicureans ${ }^{21}$. [3] Finally and most introduced into it because and to the importantly, Karamanolis' argumentum e extent that they can be reconciled with it. silentio insufficiently takes into account

The third general argument that I would like to discuss focuses on Plutarch's way of criticising Aristotle. Karamanolis shows very well that Plutarch frequently disagrees with Aristotle but nevertheless often refrains from attacking him explicitly. The question remains, however, how this approach should be understood. Once again, Karamanolis regards this as an indication that "Plutarch considers Aristotle as somehow belonging to the Platonist tradition"20. This, however, is far from certain. [1] First of all, alternative explanations are possible, from Plato's Timaeus), and now and then e.g., the suggestion that Plutarch did mentions Aristotle in passing when he not regard Aristotle's specific position regards the latter's position as somehow on a given topic as important enough relevant or worth mentioning. Deriving to discuss it in detail. [2] Secondly, general conclusions about Plutarch's Karamanolis' argument ignores the fact attitude towards Aristotle from the absence that other philosophers who no doubt of direct criticism in such passages merely belong to the Platonist tradition are no reflects our own bias and interests, but less criticised by Plutarch, nominatim fails to do justice to Plutarch ${ }^{24}$.

19 As was demonstrated very well by D. BABUT, 1969a, pp. 71-80.

20 G.E. Karamanolis, 2006, p. 89; cf. also pp. 115 and 125-126.

21 E.g. Speusippus (Quaest. Plat. 1007AB), Xenocrates and Crantor (De an. procr. 1013B).

22 The passage is analysed in detail by A.P. Bos, 1999.

23 G.E. Karamanolis, 2006, p. 111.

24 A similar argumentum e silentio, and equally problematic in my view, is to be found on p. 115, where Karamanolis correctly argues that Plutarch "is likely to have regarded Aristotle's view on the divine intellect as preserving only part of Plato's doctrine", but again regards the absence of any criticism on Plutarch's part to be significant. 
Karamanolis further points to two interesting features of Plutarch's criticism of Aristotle. [1] Sharp criticism often has to yield to an emphasis on points which Plato and Aristotle have in common. While this feature is to a certain extent rather rooted in Karamanolis' reconstruction than in Plutarch himself, it generally proves true for Plutarch's polemical treatises, where, however, it should mainly be understood as an eristic strategy: Plutarch tries to isolate his philosophical opponents and to add more authority to his own point of view by connecting as many famous thinkers as possible with his own position. Aristotle is only one of the philosophers who are used in this way ${ }^{25}$, which may suggest that this feature should often be explained by polemical advantages rather than by philosophical affinity. [2] When Plutarch does criticise Aristotle, he does it mildly and constructively. It is clear of course that this supposed feature is intimately connected to Karamanolis' basic hypothesis - it risks to be merely an intelligent $a d h o c-$, but as far as I can see, any cogent evidence for it is simply lacking. To regard a criticism as mild or severe is often almost a matter of taste, inct and in any case Karamanolis himself Basically the same tradition can be found agrees - correctly to my mind - that in De Is. et Os. 369D-371A (where other Plutarch's attack on Aristotle in Adversus thinkers are added) ${ }^{28}$. These passages

26 G.E. Karamanolis, 2006, p. 99: "The language Plutarch uses suggests that for him the Forms constitute the higher causes; so by rejecting them, Aristotle's causal explanations are philosophically inadequate. For Plutarch, this is not a small shortcoming for a philosopher."

27 P. Donini, 1999.

28 Cf. also J. MANSFELD, 1992, pp. 278-290.
Colotem $1115 \mathrm{DE}$ is severe enough ${ }^{26}$.

Lack of space does not allow me to provide more detailed analyses of several crucial passages (such as Adv. Colot. 1115A-C). In general, Karamanolis' study is not without merit. He has discussed a wealth of relevant material and often vations. His general interpretation of Plutarch, however, is in my view rather problematic, and only leads us further into the dark labyrinth. If we would like to escape from the monster of unfounded hypotheses, we better refrain from attributing to Plutarch the conviction that Aristotle was an exponent of the Platonist tradition to which he belonged himself.

\subsection{Aristoteles Pythagoricus}

There may, however, be another interesting way out of the labyrinth, as was shown by Donini ${ }^{27}$. He takes as his point of departure the well-known doxographic passage near the beginning of De virtute morali, where Plutarch refers to a philosophical tradition that begins with Pythagoras, culminates in Plato, and ncludes Aristotle as well (441D-442C). provides valuable and innovative obser- 
show, according to Donini, that Plutarch of his Stoic opponents is at odds with the placed Aristotle in a Pythagorean-Platonic communis opinio of several distinguished philosophical tradition.

Donini then most interestingly opposes this tradition to another one, which he finds in Adversus Colotem. This family includes several Presocratics (Democritus, Empedocles, Parmenides), Socrates, Plato, and the Academy (Arcesilaus and Carneades), but strikingly omits precisely Pythagoras and Aristotle. We thus obtain two distinct philosophical families. There is one problem, however, which remains and which Donini is unable to solve, that is, Plato is placed in two different philosophical traditions. Is there any indication that would enable us to choose between them?

In all likelihood, there is no reason at all why we should prefer one to the other. In fact, Donini's position is alleged philosophical family as the not unproblematic. As far as the first scope of Colotes' work. This is not to philosophical family is concerned, he deny, to be sure, that Colotes' opponents erroneously disregards the polemical could be related with good arguments to context of the treatise. Plutarch's one another in a specific philosophical philosophical loyalty here as always domain (e.g. epistemology), but such remains with Plato. Both Pythagoras an occasional conglomerate should not and Aristotle are linked to the Platonic be isolated from its (polemical) context, position because [1] such a link, of course, and moreover, I see no reason, apart from is possible in this particular context ${ }^{29}$, Colotes' selection, why this second family because [2] it thus shows that the position should necessarily be confined to the

29 In that sense, Donini's point remains valid: Plutarch indeed seems to have established such a philosophical connection in the specific context of De virtute morali; cf. also A. Bellanti, 2003. What I deny, however, is that this conclusion holds true for the Corpus Plutarcheum in general.

30

In all likelihood, Colotes was convinced that he sufficiently refuted Aristotle through his attack on Plato, cf. Adv. Colot. 1115A and C. 
philosophers mentioned by Plutarch ${ }^{31}$.

To conclude, the importance of the two philosophical families as reconstructed by Donini should not be overemphasised: the first is introduced pour le besoin de la cause, the second is the direct result of Colotes' attack. As such, the passages do not provide much information about Plutarch's general position towards Aristotle, and Donini's path, interesting though it may be, likewise comes to an end in the darkness of the labyrinth.

\section{From darkness to light}

\subsection{Ariadne's thread: Aristoteles Peri-} pateticus

Are we doomed, then, to be swallowed up by the monster of ignorance? Perhaps only a systematic analysis of the whole labyrinth can still rescue us. This in the first place implies a systematic examination of all passages where Aristotle is connected with other philosophers. If this should be our thread of Ariadne, it is clear from the very beginning how fragile this thread actually is. For given that all passages should be understood in the light of their specific context, one easily sees how yet another monster, that of oversimplification, waits in ambush. A mere list of passages, then, will not do, but has to be corroborated by an additional perspective.

Ingeneral, the following fourcategories of passages can be distinguished in Plutarch's works:

[1] The majority of passages contain occasional combinations of philosophers from different traditions. The link between these philosophers is always coincidental and directly related to the context, and does not illustrate any more general philosophical congeniality. A brief survey without much further discussion suffices:

- De prof. in virt. 78C-E: Solon-Diogenes - Agesilaus - Aristotle - Zeno

(the whole cluster can be traced back to one of Plutarch's vं cf. also De tranq. an. 472DE and De se ipsum laud. $545 \mathrm{~A}^{32}$ )

- De Is. et Os. 369D-371 A: Zoroaster - the Chaldaeans - Heraclitus - Empedocles - Pythagoras - Anaxagoras - Aristotle - Plato

(all endorsing a basically dualistic philosophy)

- De virt. mor. 441E-442C: Pythagoras - Plato - Aristotle (doxographic passage, connected with the polemical context of the treatise; cf. supra)

- De virt. mor. 448A: Aristotle Democritus - Chrysippus (all three retracted some of their doctrines)

31 We may note that according to G.E. Karamanolis, 2006, p. 86, "there is evidence to suggest that Plutarch perceived Aristotle's accord with Plato's philosophy partially through Aristotle's adherence to his aporetic spirit."

32 See L. VAn der Stockt, 1999, and G. Roskam, 2005a, pp. 260-265. 
- Quaest. conv. 612DE: Plato -Xenophon which Plutarch has for the Stagirite. In - Aristotle - Speusippus - Epicurus many cases, their juxtaposition is again - Prytanis - Hieronymus - Dio directly related to the context, and often (all authors of Symposium literature) based on superficial correspondences. In

- Quaest. conv. 616D: Aristotle - Thrasy- that sense, most passages could equally machus (both authors of logical treatises)

- Quaest. conv. 652A: Aristotle Epicurus (both writing on the same topic)

- De facie 932BC: Aristotle - Posidonius (both writing on the same topic) well be ranged under the first category:

- De aud. poet. 26B (on Plato's stoop and Aristotle's lisp; cf. also De ad. et am. 53CD, where the pair is completed by Alexander's twisted neck and harsh voice)

- De Is. et Os. 382D (both called the contemplation of the intelligible world the epoptic part of philosophy ${ }^{33}$ )

Speusippus - the Stoics (all three proposing a wrong definition of time; against Pindar, Pythagoras, and Plato)

- Non posse 1086EF: Aristotle Socrates - Pythagoras - Protagoras - Theophrastus - Heracleides - Hipparchia (all abused by the Epicureans)

- De E 389F (on the number of worlds)

-DeStoic. rep. 1040A-1041B (Chrysippus as the opponent of both Plato and Aristotle)

There are two passages which deserve special attention in this category:

- Non posse 1093BC: Eudoxus - Aristotle - Aristoxenus

- De Is. et Os. 375C (important (all authors of works the reading of which brings great pleasure; together with Herodotus and Xenophon)

- Adv. Colot. 1124C: Plato - Aristotle - Theophrastus - Democritus (all attacked their predecessors) agreement between Plato and Aristotle in their conception of the divinity)

- Quaest. Plat. 1006D (Aristotle's definition of the soul is inadequate to explain a passage from Plato's Timaeus)

It is clear that both passages seem to favour diametrically opposed conclusions. Both,

[2] Fairly often, Plato and Aristotle however, should be understood in their are juxtaposed as two great philosophical own context, and neither can be used to authorities. While this does not imply that reach more general conclusions about Plutarch places both at the same level, it Plutarch's attitude towards Aristotle (and obviously illustrates the great esteem the latter's relation with Plato).

33 On the connection of philosophy and mystery cults in Plutarch's work, see G. RosKAM, 2001; cf. also P. VAn Nuffelen, 2007. 
[3] In four passages, Aristotle is connected with Academic philosophers:

- Cons. ad Apoll. 115B: Crantor - Aristotle

(This passage, however, need not detain us: the connection between both philosophers seems rather arbitrary both made approximately the same point - and need not imply a more fundamental philosophical congeniality.)

- De comm. not. 1069A: Aristotle - Xenocrates

(Both agree that men are benefited by gods, parents, and teachers, but do not deal with the mutual benefits which sages receive from one another. The passage thus suggests a basic agreement between both thinkers, without, however, placing them explicitly in the same philosophical tradition. It is perfectly possible that both are introduced as authorities of different schools, who both disagree with the Stoic point of view. If this is indeed true, it would yield Plutarch an additional polemical advantage, in that the Stoics thus prove to be even more isolated and at odds with the great authorities of two different philosophical traditions.)

- Adv. Colot. 1111D: Plato - Aristotle - Xenocrates

(The three agreed on the doctrine of the four elements, against Epicurean atomism. Just like in the previous passage, the fundamental agreement of the famous philosophers is underlined and confronted with the view of Plutarch's opponents. Again, however, this juxtaposition in all likelihood mainly reflects Plutarch's eristic strategy.)

-Adv. Colot. 1126CD: Plato-Aristonymus - Phormio - Menedemus - Eudoxus - Aristotle - Xenocrates - Delius - Zeno of Elea

(This is a very important passage, for here, Aristotle is explicitly and unambiguously regarded as belonging to the Academic tradition. Plutarch points to the many political achievements of Plato's students. After recalling some minor figures, he turns to Eudoxus of Cnidus and Aristotle, who both acted as legislator for their country, and emphasises that both were

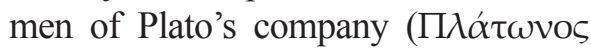

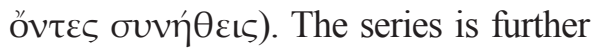
completed by Xenocrates, Delius of Ephesus (again characterised as a follo-

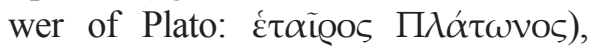
and Zeno of Elea (the only Presocratic philosopher in the list). In all likelihood, the polemical context of the passage makes its influence felt here as well, but Plutarch's clear statement, even if it stands alone in the Corpus Plutarcheum, should not be explained away. We shall have to return to it in due course.)

[4] In a great number of passages, finally, Aristotle is connected with the Peripatetic tradition. Once again, this connection frequently rests on a merely superficial basis: 
- Quaest. conv. 704EF: Aristoxenus - - opposition Peripatos - Academy: most Aristotle (mentioned after each other about related themes)

- Adv. Colot. 1126F: Aristotle-Theophrastus (both benefited their native city)

- cf. also [Dec. or. vit.] 850C: Theophrastus - Aristotle (Theophrastus as Aristotle's successor as scholarch of the Lyceum)

- cf. also De cup. div. 527AB: Aristotle Theophrastus (their opinion on wealth)

Other passages, however, where Plutarch distinguishes between different philosophical schools, are of paramount importance in the context of this study, for there, Plutarch himself explicitly says in what philosophical tradition he places Aristotle. In these passages, which obviously contain by far the most cogent evidence, Aristotle is nearly always situated in the Peripatetic tradition:

- Quaest. conv. 635AB: $\Lambda \alpha \mu \pi \mathrm{Q} \alpha$ ḋ̀ $\kappa \alpha i$

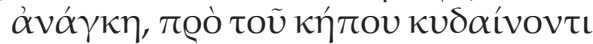

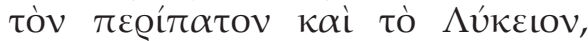

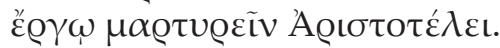

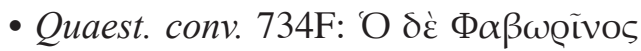

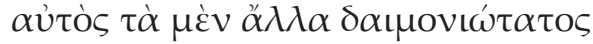

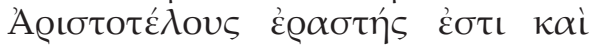

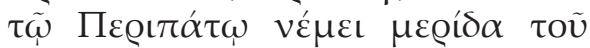
$\pi \mathrm{\imath} \theta \alpha$ võ $\pi \lambda \varepsilon \dot{\sigma} \sigma \tau \eta v$.

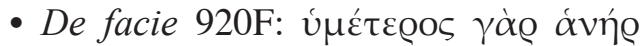

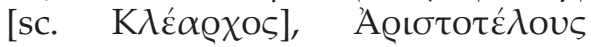

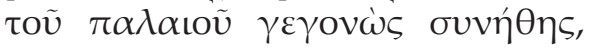

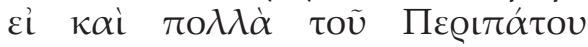
$\tau \alpha \varrho \varepsilon ́ \tau \varrho \varepsilon \psi \varepsilon v$.

Sometimes the Peripatetic school, with Aristotle as its standard bearer, is opposed to other philosophical schools: clearly in Adv. Colot. 1115A-C, where Plutarch strongly underlines that Aristotle, and with him many of the Peripatetics (Theophrastus, Heracleides, Dicaearchus, and Strato) continuously disagreed with Plato concerning the most fundamental and important issues in physics.

Cf. also De exilio 603BC, where Plutarch refers to the Academy as the dwelling place of Plato, Xenocrates, and Polemon, and then goes on to deal with Aristotle's living at the Macedonian Court.

Cf. also De Stoic. rep. 1045F-1046A,

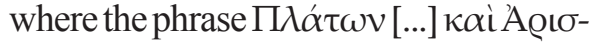

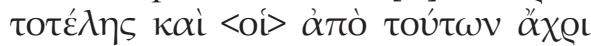

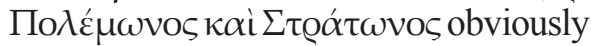
refers to the Academic tradition from Plato to Polemon, and the Peripatetic tradition from Aristotle to Strato.

- opposition Peripatos - Stoa: De exilio $605 \mathrm{AB}$, where Plutarch names many members of both the Peripatetic and the Stoic school tradition: $\varepsilon i$ in่ $\Pi \varepsilon-$

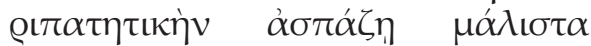

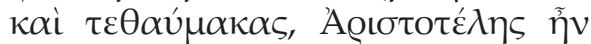

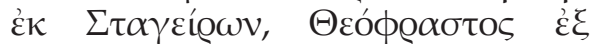

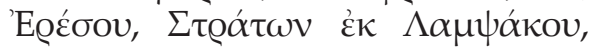

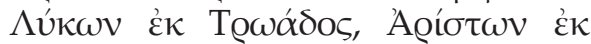

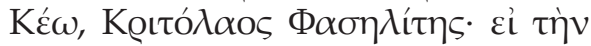

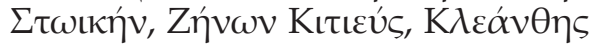

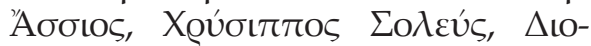

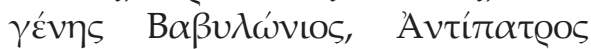

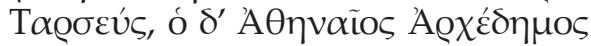

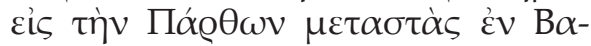

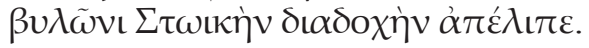

- opposition Peripatos - Academy Stoa: De comm. not. 1069E, where Chrysippus' wrong starting points are 
opposed to the correct ones of Aristotle more explicitly thematises this question, and Theophrastus, of Xenocrates and however, he nearly always regards Polemon, and of Zeno.

Aristotle as belonging to the Peripatetic There finally remains one more ambivalent passage to be discussed in this category:

- Non posse 1097B, where Plutarch deals with the great pleasures Plato, Aristotle, Theophrastus, and Phanias derived from their famous political accomplishments. Plutarch nowhere explicitly argues that Aristotle and the Peripatetics should directly be connected with the Academic political tradition beginning in Plato, yet it may be regarded as an important complement to the parallel passage discussed above ( $A d v$. Colot. 1126CD). As far as politics is concerned (and in an anti-Epicurean context), Plutarch appears to establish a close link between the Platonic-Academic and the Aristotelian-Peripatetic tradition.

On the basis of this survey, we may conclude that the great majority of passages contains but little cogent evidence concerning the philosophical tradition in which Plutarch places Aristotle. When different philosophers are mentioned next to each other, the historical source ${ }^{34}$, and no less often as link is often fairly arbitrary and directly the authoritative source on all kinds of related to the context. Where Plutarch physical and biological issues ${ }^{35}$. Plutarch

34 See, e.g., Mul. virt. 254F (= fr. 559 Rose); Amatorius 761A (= fr. 98 Rose); cf. Non posse 1093C. In the Lives, Aristotle is nearly always quoted as a historical source. Especially

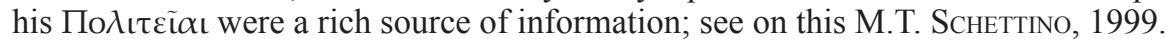

35 See, e.g., De tuenda 133F (= fr. 233 Rose); De Is. et Os. 383D; De Pyth. or. 395F; De def. or. 430A and 434B; Quaest. conv. 702B (= fr. 224 Rose); 720D; 727EF (= fr. 353 Rose); 734E (= fr. 242 Rose); Quaest. nat. 911E; 912A (= fr. 215 Rose); 914F; De facie 932BC 
also refers to Aristotle's literary studies ${ }^{36}$, borrows anecdotes and antiquarian information $^{37}$ from him, repeatedly praises his political achievements ${ }^{38}$, and recalls some of his ethical views ${ }^{39}$. It is striking that more fundamental philosophical problems remain absent from the list. Particularly noteworthy, however, are the remarkable similarities with Plutarch's use of Theophrastus. Near the end of Boulogne's careful and exhaustive study of this topic, we can read ${ }^{40}$ :

Outre que le comportement public et politique de ce dernier [sc. Théophraste] lui [sc. Plutarque] fournit ponctuellement une aide dans sa polémique anti-épicurienne [...], il pense, semble-t-il, à consulter presque systématiquement ses ouvrages, parce qu'ils font partie des lectures indéniablement utiles. Il y trouve des réponses aux questions qu'on peut se poser face à des problèmes d'ordre scientifique [...], ou tout au moins des éléments de solution importants [...]. Mais c'est également une mine à la fois d'informations pour l'histoire et de bonnes formules, qu'il s'agisse de sentences ou d'aphorismes énonçant des vérités morales.

The general resemblances between Plutarch's use of Aristotle and of Theophrastus are too obvious to demand detailed and pedantic discussion. Both Peripatetic philosophers are frequently quoted as sources of erudite and valuable observations, and provide interesting starting points for further thinking. More fundamental explanations, however, are usually derived from Plato and his followers. For Plutarch, in short, the Peripatetics appear to be especially interesting on the level of heuristics.

\subsection{A last necessary delay}

The above evidence clearly shows that Plutarch regards Aristotle as a Peripatetic philosopher. Strictly speaking, the Stagirite thus belongs to a philosophical tradition that differs from the Platonism to which Plutarch himself belongs. Such a simplifying conclusion, however, cannot be the last word. It is not merely contradicted by the evidence of some

(= fr. 210 Rose); De prim. frig. 948A and 949C (= fr. 212 Rose); Aquane an ignis 956C; De soll. an. 973AB; 978D; 979E; 981B (= fr. 354 Rose); 981EF; fr. 72 Sandbach.

36 De aud. poet. 32F (= fr. 165 Rose); De Pyth. or. 398A (cf. fr. 130 Rose); Comp. Ar. et Men. 853F; Quaest. nat. 917CD; Non posse 1095A and E.

37 Quaest. Rom. 265BC (= fr. 609 Rose) and 277BC; Quaest. Graec. 292B (= fr. 592 Rose); 294D (= fr. 507 Rose); 295EF (= fr. 597 Rose).

E.g. in his Life of Alexander, esp. 7,1-8,3; cf. further De Al. Magn. fort. 327EF; De Stoic. rep. 1043D; Non posse 1097B; Adv. Colot. 1126D and F; see also infra, section 3.2.3.

39 Pel. 3,1 (= fr. 56 Rose); De prof. in virt. 78DE; De coh. ira 454C; De tranq. an. 472E; De gar. 503AB; De se ipsum laud. 545A; fr. 53 Sandbach.

40 J. Boulogne, 2005, p. 293. 
passages - however isolated they may Stoics, who again and again are insulted be -, but also seems to run counter to De and blamed for their utter ignorance ${ }^{41}$. virtute morali, where Plutarch without Between these opposed poles can be found problem presents Peripatetic material Theophrastus, the "most versatile and as thoroughly Platonic. This raises the learned of the philosophers" $($ Alc. 10,3) and question of the precise position of the Aristotle ${ }^{42}$. The latter obviously belongs

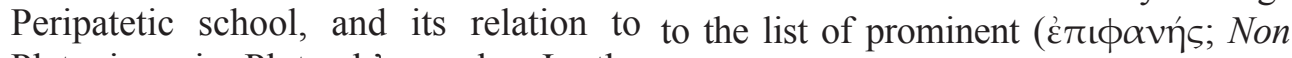

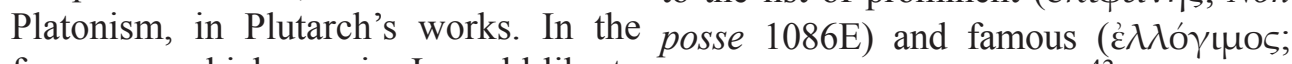
few pages which remain, I would like to $A d v$. Colot. 1124C) thinkers ${ }^{43}$, and in De confine myself to deal briefly with three aspects of this complex problem which all three point in the same direction and together lead to what I regard as a possible way out of the labyrinth.

3.2.1. The first aspect which provides already we meet the typical ambivalence helpful information concerns Plutarch's which we will find back with regard to explicit evaluations of different philo- the next two aspects as well: Aristotle no sophers. Plato of course towers above doubt deserves much respect and often everybody else, being not merely "pre- approaches Plato's level, yet there remains eminent in reputation and in influence" a gap which is never bridged.

(Quaest. conv. 700B) but even "divine" (De cap. ex inim. 90C and Per. 8,2). Stoic. rep. 1041A, he is even juxtaposed to

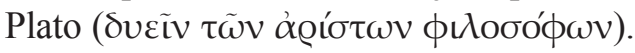
On the other hand, there can be found several passages where Aristotle is explicitly criticised by Plutarch ${ }^{44}$. Here Quite close to Plato is Xenocrates, who mutatis mutandis be made for the domain at least in one case seems to have reached of Plutarch's ethics. As has been said, De his conclusions by divine reasoning virtute morali contains many Aristotelian

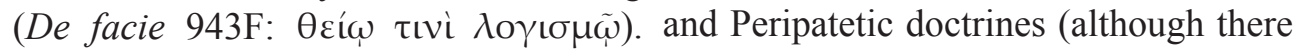
The counterparts of these distinguished can usually be found minor differences philosophers are the Epicureans and the with Aristotle's Ethics ${ }^{45}$ ). First of all, it is

41 See G. Roskam, 2004, pp. 271-272.

42 For Plutarch's general judgement of Aristotle, see also D. BABUT, 1996, pp. 23-26.

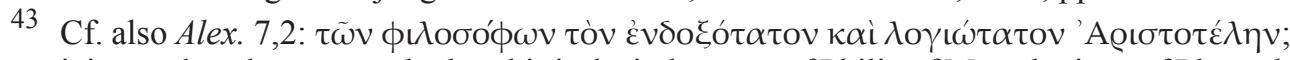
it is not clear, however, whether this is the judgement of Philip of Macedonia or of Plutarch himself.

44 Cf. also D. BABut, 1996, p. 23: "S'il est vrai que ce jugement [...] est globalement assez favorable, il n'en reste pas moins que l'auteur des Moralia n'hésite pas, à l'occasion, à critiquer nommément le fondateur de l'école péripatéticienne, ce qu'il ne fait jamais, il faut le souligner, quand il s'agit de Platon."

45 See B. Babut, 1969a, ad loc.; P. Donini, 1974, pp. 71-77; F. BeCchi, 1990, ad loc. F. 
important to underline that Plutarch's use and that Aristotelian flavour should not of these doctrines is directly connected be regarded as an omnipresent and / with the polemical purpose of the treatise. or structural component of Plutarch's At the level of heuristics, Plutarch no ethical philosophy. In this case too, the doubt found much relevant material in the tension between attraction and distancing Peripatetic tradition which he could use for reappears.

his anti-Stoic attack, and as in other antiStoic polemics, Aristotle could also be quoted as an argumentum ex auctoritate. On the other hand, Plutarch's use of Aristotelian doctrines in De virtute morali cannot be reduced to a mere technique which yields a significant polemical advantage. Plutarch quite unambiguously introduces the Aristotelian doctrines as orthodox Platonic philosophy. Such an appropriation is typical of Middle Platonist ethics ${ }^{46}$ and again illustrates how closely Aristotle and Plato can be connected in Plutarch's mind.

3.2.3. The same tension comes to the fore even more in the field of political philosophy and praxis. As usual, Plutarch in this domain follows Plato ${ }^{48}$, but here too, Aristotle and the Peripatetic tradition play a special role, which somehow recalls the case of De virtute morali. This appears from evidence which is usually ignored, viz. biographical information about Aristotle's political achievements. In view of the importance which Plutarch - and many others - attached to consistency between words and deeds ${ }^{49}$, this evidence is unduly neglected, even

Again, however, this appropriation more so because Plutarch appears to take never results in a complete fusion. This Aristotle very seriously in this respect. clearly appears from Plutarch's treatises The Stagirite's relation with Alexander of Seelenheilung, where several aspects is both thematised in Plutarch's Life of Aristotelian and Peripatetic ethics of Alexander (esp. 7,2-8,3) and in his are sharply rejected ${ }^{47}$. Such occasional rhetorical work De Alexandri fortuna criticisms show that Plutarch's ethics aut virtute (327EF). No less attention does not coincide with De virtute morali is given to Aristotle's role as the great

BECCHI, 1975, p. 162 correctly insists that perfect correspondences between Plutarch and Aristotle cannot even be expected, in view of the long philosophical tradition that separates both thinkers; cf. also ID., 1978, p. 263.

46 Cf. supra, note 17.

47 See, e.g., Quaest. conv. 704F; De an. procr. 1025D; fr. 148 Sandbach (with G. RoskAm, 2003, pp. 48-49); on De ad. et am. 66C, see D. BABUt, 1969a, p. 78 versus F. BECCHI, 1975, p. 175.

48 See, e.g., G.J.D. Aalders, 1982, p. 41; G.J.D. Aalders \& L. DE Blois, 1992, pp. 33903391; J.P. HeRSHBELL, 1995, p. 213.

49 See G. Roskam, 2005a, pp. 320-335. 
benefactor of his native city Stageira. to overlap to an important extent. This Philip indeed restored the city, which helps to explain the striking passages, he had himself destroyed, as Aristotle's discussed above (cf. supra, 3.1, on $A d v$. teacher's fee (Alex. 7,2; De Stoic. rep. Colot. 1126CD and Non posse 1097B), 1043D; Non posse 1097B; Adv. Colot. where Aristotle is placed in the Academic $1126 \mathrm{~F}$ ), and moreover, the philosopher tradition of political activity.

would also have acted as a legislator for Stageira (Adv. Colot. 1126D). All these political accomplishments are praised and prove to be in line with Plutarch's own political ideal of the honourable course

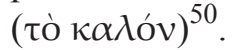

It may be added that a similar picture is frequently attacked in Plutarch's can be found with regard to Aristotle's work ${ }^{51}$ and his notorious doctrine of $\lambda \alpha^{\prime}$ successors. Both Theophrastus (Non $\theta \varepsilon \beta \mathrm{t} \omega \sigma \sigma \alpha \varsigma$ is criticised at length in De posse 1097B; Adv. Colot. 1126F) and latenter vivendo ${ }^{52}$. Isocrates is hardly Phanias of Eresus (Non posse 1097B = better, for he never served the state, fr. 7 Wehrli) would have delivered their although he had ample opportunity to do native cities from tyrants, Cratippus so, but instead preferred to pass his entire associated with powerful Roman rulers life composing his polished periods (Pomp. 75,3-4; Brut. 24,1; Cic. 24,5), (Bellone an pace 350D-F) ${ }^{53}$. The most and Demetrius of Phalerum for a while interesting case, finally, are the Stoics. governed Athens as the most powerful Plutarch finds little difficulty in attacking man in the city (Demetr. 8,3 and 10,2). Zeno, Cleanthes, and Chrysippus for their As such, the Aristotelian-Peripatetic inconsistency in this domain: even though tradition can indeed be compared very the scholarchs devoted many works to well with the Platonic-Academic one, political philosophy, they never engaged for Plato's successors likewise engaged into politics themselves (De Stoic. rep. in public life and were often successful 1033BC). Here too, active participation in in their ambitious political projects (see public life serves as the decisive criterion. esp. Adv. Colot. 1126CD). Once again, Yet the Stoics' case is somewhat more both philosophical traditions thus prove complicated, for Plutarch knew perfectly

50 For Plutarch's convictions regarding the correct motivations of the politician (viz. tò

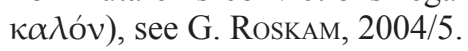

51 See G. Roskam, 2005b.

52 See G. Roskam, 2007a.

53 That Plutarch was nonetheless influenced by Isocrates' political thinking has been argued by L. DE Blois \& J.A.E. Bons, 1992 and ID., 1995. 
well that there were many examples was criticised as being at odds with the of Stoics who did enter into public life philosopher's independence (De exilio and contributed to the public interest. 603C and 604D), and Plutarch further Paradigm par excellence in this respect argues thatAlexanderwas entirelyjustified is of course Cato of Utica, but Sphaerus in disregarding Aristotle's political advice (Cleom. 2,2 and 11,2), Persaeus (Arat. (De Al. Magn.fort. 329BC). He also often 18,1), Blossius (TG 8,4-5;17,4; 20,3- recalls the unenviable fate of Demetrius 4), Crates of Mallos (Non posse 1095D), of Phalerum, who had to witness how his and Panaetius (Maxime cum principibus three hundred statues were demolished 777AB) likewise engaged in politics by (Praec. ger. reip. 820EF). In that sense, associating with powerful rulers. Yet the same tension between attraction and in Plutarch's eyes, their achievements distancing returns. In both ethics and remain problematic. They even prove to politics, Plutarch appears to be inclined be more inconsistent than their apolitical to consider the position of Aristotle and scholarchs, in that they, by entering his followers as strikingly close to that public life, prove to take seriously the of Plato, without, however, implying that existing states and all those politicians both completely coincide.

who according to their doctrines are ordinary and silly idiots (De Stoic. rep. 1033EF). Their philosophy does simply

\section{Conclusion}

In all likelihood, Plutarch considered not provide an adequate basis for political Aristotle as the first Peripatetic philoengagement. If that is true, we can only sopher, which implies that he did not conclude that in Plutarch's eyes, the regard him as a full member of his own Academic and Peripatetic tradition has a philosophical school. Plutarch's view monopoly position with regard to correct was no doubt less radical than that of and useful participation in politics. In this Atticus, yet in my view, he was no early domain, Aristotle indeed proves to be a precursor of later Neoplatonists such like faithful pupil of Plato.

Just as in the above discussed case of Plutarch's ethics, however, this conclusion is in need of some qualification. Here as well, Aristotle's great political the Platonic and the Peripatetic schools achievements are frequently emphasised from one another, sometimes this clearin a specific, polemical context, as one cut distinction fades away and the two of the authoritative counterexamples of schools closely approach each other. apolitical Epicureanism. In other contexts, I would suggest, on the basis of the Plutarch proves much more critical of evidence discussed above, that Plutarch Aristotle. His presence at Philip's Court regards the Peripatetic school [1] as 
basically different from the Platonic one, [2] but at the same time as the privileged ally among other philosophical schools (together, perhaps, with Pythagoreanism). On several domains, the similarities between the Platonic and the Peripatetic position more than suffice to form a united front, but equally often, the two philosophical paths again separate and clear indications of Plutarch's critical distancing can be found.

In my view, only such a conclusion can lead us as Ariadne's thread out of the labyrinth. Yet I do not claim to have reached the exit and survey in full clarity the solution of all problems, nor to have overcome all possible monsters. No doubt the final answer to this much discussed set of questions requires a more elaborate and detailed analysis of (several crucial passages from) the Corpus Plutarcheum. At the end of this modest contribution, I would be satisfied already if guided by this thread of Ariadne, our hesitating steps in the dark labyrinth at last gradually begin to approach the brilliant daylight.

\section{BIBLIOGRAPHY}

AALDERs, G.J.D.,

- Plutarch's Political Thought, Amsterdam - Oxford-New York, 1982 (Verhandelingen der Koninklijke Nederlandse Akademie van Wetenschappen, Afd. Letterkunde, NR 116).

Aalders, G.J.D. \& de Blois, L.,

- "Plutarch und die politische Philosophie der Griechen", in $A N R W$ II, 36, 5, Berlin - New York,1992, pp. 3384-3404.

BABUT, D.,

- Plutarque. Dela vertuéthique. Introduction, texte, traduction et commentaire, Paris,
1969 (Bibliothèque de la Faculté des Lettres de Lyon 15) [=1969a].

- Plutarque et le stoïcisme, Paris, 1969

(Publications de l'Université de Lyon) [=1969b].

"Plutarque, Aristote, et l'Aristotélisme", in L. VAn DeR Stockt (ed.), Plutarchea Lovaniensia. A Miscellany of Essays on Plutarch, Lovanii, 1996 (Studia hellenistica 32), pp. 1-28.

BECCHI, F.,

- "Aristotelismo ed antistoicismo nel De virtute morali di Plutarco", Prometheus, 1 (1975) 160-180.

"Aristotelismo funzionale nel 'De virtute morali' di Plutarco", Prometheus, 4 (1978) 261-275.

- Plutarco. La virtú etica. Testo critico, introduzione, traduzione e commento, Napoli, 1990 (Corpus Plutarchi Moralium 5).

Bellanti, A.,

"Aristotele Pitagorico? La concezione della medietà nel De virtute morali di Plutarco", RFN, 95 (2003) 3-36.

Bos, A.P.,

- "Plutarch's Testimony to an Earlier Explanation of Aristotle's Definition of the Soul", in A. Pérez JimÉnez \& J. García LóPez \& R.M. Aguilar, 1999, pp. 535-548.

Boulogne, J.,

- "Plutarque lecteur de Théophraste", in A. Casanova(ed.), Plutarco el'età ellenistica. Atti del Convegno Internazionale di Studi, Firenze, 23-24 settembre 2004, Firenze, 2005, pp. 287-300.

DE Blois, L. \& Bons, J.A.E.,

- "Platonic Philosophy and Isocratean Virtues in Plutarch's Numa", AncSoc, 23 (1992) 159-188.

"Platonic and Isocratean Political Concepts in Plutarch's Lycurgus", in I. Gallo \& B. Scardigli (eds.), Teoria e prassi politica nelle opere di Plutarco. Atti del V Convegno plutarcheo (Certosa di Pontignano, 7-9 giugno 1993), Napoli, 
1995, pp. 99-106.

Donini, P.,

- Tre studi sull'aristotelismo nel II secolo D. C., Torino, 1974 (Historica politica philosophica. Il pensiero antico - studi e testi 7).

- "Platone e Aristotele nella Tradizione Pitagorica secondo Plutarco", in A. PÉREZ JimÉnez \& J. García López \& R.M. Aguilar, 1999, pp. 9-24.

FERRARI, F.,

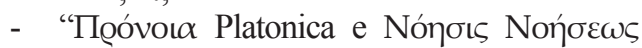
Aristotelica: Plutarco e l'impossibilità di una Sintesi”, in A. PÉrez JimÉnEZ \& J. GARCíA LÓPEZ \& R.M. AguILAR, 1999, pp. 63-77.

GRÉARD, O.,

- De la morale de Plutarque, Paris, 1885.

Hershbell, J.P.,

- "Paideia and Politeia in Plutarch: The Influence of Plato's Republic and Laws", in I. Gallo \& B. Scardigli (eds.), Teoria e prassi politica nelle opere di Plutarco. Atti del V Convegno plutarcheo (Certosa di Pontignano, 7-9 giugno 1993), Napoli, 1995, pp. 209-219.

HiLlyard, B.P.,

- Plutarch: De audiendo. A Text and Commentary, Salem, NH, 1981 (Monographs in Classical Studies).

Karamanolis, G.E.,

- Plato and Aristotle in Agreement? Platonists on Aristotle from Antiochus to Porphyry, Oxford, 2006.

MANSFELD, J.,

- Heresiography in Context. Hippolytus' Elenchos as a Source for Greek Philosophy, Leiden - New York - Köln, 1992 (Philosophia antiqua 56).

NiKOLAidis, A.G.,

- "Plutarch on the Old, Middle and New Academies and the Academy in Plutarch's Day", in A. PÉrez JimÉnez \& J. García LóPEZ \& R.M. Aguilar, 1999, pp. 397-415.

Opsomer, J.,

- 'Divination and Academic 'Scepticism' according to Plutarch", in L. VAN DER Sтоскт (ed.), Plutarchea Lovaniensia. A Miscellany of Essays on Plutarch, Lovanii, 1996 (Studia Hellenistica 32), pp. 165-194. In Search of the Truth. Academic Tendencies in Middle Platonism, Brussel, 1998 (Verhandelingen van de Koninklijke Academie voor Wetenschappen, Letteren en Schone Kunsten van België. Klasse der Letteren 60, 163).

Pérez Jiménez, A. \& García López, J. \& AguiLAR, R.M. (eds.),

- Plutarco, Platón y Aristóteles. Actas del V Congreso Internacional de la I.P.S. (Madrid - Cuenca, 4-7 de Mayo de 1999), Madrid, 1999.

Roskam, G.,

- “'And a Great Silence filled the Temple...' Plutarch on the Connections between Mystery Cults and Philosophy", in A. PÉrez Jiménez \& F. CASAdesús Bordoy (eds.), Estudios sobre Plutarco. Misticismo y religiones mistéricas en la obra de Plutarco. Actas del VII Simposio Español sobre Plutarco (Palma de Mallorca, 2-4 de Noviembre de 2000), Madrid - Málaga, 2001, pp. 221-232.

"Being the Physician of one's own Soul. On a Plutarchan Fragment on Anger (fr. 148 Sandbach)", in J. Ribeiro Ferreira \& D. Ferreira LeÃo (eds.), Os fragmentos de Plutarco e a recepção da sua obra [= Humanitas 55], Coimbra, 2003, pp. 41-62. "Plutarch on Self and Others", AncSoc, 34 (2004) 245-273.

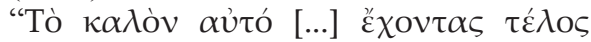
(Praec. ger. reip. 799A). Plutarch on the Foundation of the Politician's Career", Ploutarchos, NS 2 (2004/5), 89-103.

- On the Path to Virtue. The Stoic Doctrine of Moral Progress and its Reception in (Middle-)Platonism, Leuven, 2005 (Ancient and Medieval Philosophy, Ser. 1, 33) $[=2005 \mathrm{a}]$.

"The Displeasing Secrets of the Epicurean 
Life. Plutarch's Polemic against Epicurus' Political Philosophy", in A. CASANOvA (ed.), Plutarco e l'età ellenistica. Atti del Convegno Internazionale di Studi, Firenze, 23-24 settembre 2004, Firenze, 2005, pp. 351-368 [=2005b].

- A Commentary on Plutarch's De latenter vivendo, Leuven, 2007 [=2007a].

- 'Plutarch's Attack on Epicurus' Ideal of an 'Unnoticed Life'. Polemical Strategies in De latenter vivendo" in J.M. NIETO IBÁÑEZ \& R. LÓPez LóPEz (eds.), El amor en Plutarco, León, 2007, pp. 867-876 [=2007b].

SANDBACH, F.H.,

- "Plutarch and Aristotle", ICS, 7 (1982) 207-232.

Schettino, M.T.,

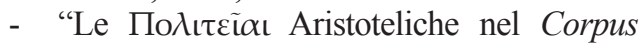
Plutarcheo", in A. PÉrez JimÉnez \& J. GARCíA LóPez \& R.M. Aguilar, 1999, pp. 643-655.

TAPPE, G.,

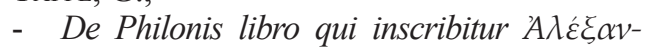

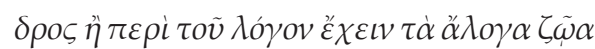
quaestiones selectae, diss. Gottingae, 1912.

VAN DER STOckT, L.,

- "Plutarch's Use of Literature. Sources and Citations in the Quaestiones Romanae", AncSoc, 18 (1987) 281-292.

"Three Aristotle's Equal but one Plato. On a Cluster of Quotations in Plutarch", in A. PÉrez JimÉnEZ \& J. García López \& R.M. Aguilar, 1999, pp. 127-140.

Van Nuffelen, P.,

- "Words of Truth: Mystical Silence as a Philosophical and Rhetorical Tool in Plutarch", Hermathena 182 (2007) 9-39.

Verbeke, G.,

- "Plutarch and the Development of Aristotle", in I. DüRING \& G.E.L. OwEN (eds.), Aristotle and Plato in the Mid-Fourth Century. Papers of the Symposium Aristotelicum held at Oxford in August, 1957, Göteborg, 1960 (Studia graeca et latina gothoburgensia 11), pp. 236-247. 